Grand Valley State University

ScholarWorks@GVSU

\title{
Value Shift: Why companies must merge social and financial imperatives to achieve superior performance
}

Carol M. Sanchez

Grand Valley State University, sanchezc@gvsu.edu

Follow this and additional works at: https://scholarworks.gvsu.edu/mgt_articles

Part of the Business Administration, Management, and Operations Commons

\section{ScholarWorks Citation}

Sanchez, Carol M., "Value Shift: Why companies must merge social and financial imperatives to achieve superior performance" (2003). Peer Reviewed Articles. 25.

https://scholarworks.gvsu.edu/mgt_articles/25

This Article is brought to you for free and open access by the Management Department at ScholarWorks@GVSU. It has been accepted for inclusion in Peer Reviewed Articles by an authorized administrator of ScholarWorks@GVSU.

For more information, please contact scholarworks@gvsu.edu. 
pain by focusing their actions in five areas. They listen with compassion to their co-workers, "providing a moment of human connection." They create both psychological and physical space where situations and emotions can be confidentially discussed. They buffer their co-workers from the harsh demands and judgmental attitudes of thoughtless bosses. They intercede on behalf of their colleagues, and finally, they oftentimes help by reframing painful situations as well as enhancing co-workers' coping mechanisms through coaching and teaching. Frost counsels, however, that this is a hazardous job and poses challenges for individuals that accept this critical responsibility. He devotes a chapter to the nature of toxin handling, the impact of toxin handling on the handler's own behavior, and the manner in which organizational policies and practices contribute to or detract from handlers' job performance and their ability to meet the emotional needs of colleagues.

Frost presents toxin handlers as individuals who seek to reduce the psychological pain of otherssubordinates, colleagues, as well as bosses-while simultaneously contributing to the health and productivity of their organizations.

After examining the concept of toxin handling from the perspective of the individual, Frost examines toxin handling through an organizational lens. He warns that toxin handlers' significant challenge will be to "garner organizational understanding of-and respect for-the work of toxin handling" and provides guidelines to aid this effort. The author also compliments firms that have realized the value of managing and diffusing organizationally based emotional pain and the contributions of these unique individuals. He recommends that organizations implement a five-fold approach designed to recognize and support toxin handlers' work. Specifically, executives and human resource professionals should acknowledge the need for this role and its relationship to productivity and profitability; provide professional support for toxin handlers by facilitating support groups, providing training, or arranging for counseling; require that toxin handlers intermittently remove themselves from this role; assure that toxin handlers, who are often perceived as professional and emotional role models, demonstrate appropriate behavior by keeping their work and personal lives in balance; and create a supportive corporate culture by weaving the work of toxin handling into the organizational fabric.

In addition to the front-line managers who include toxin handling in their array of job duties, Frost recommends that all of the organization's leaders, by virtue of their position and their impact on people, should also serve as toxin handlers. He delineates five competencies that, when acquired and demonstrated, will increase a leader's ability to act with compassion and mitigate the pain associated with everyday corporate life. These competencies include:

- Paying attention to the surrounding emotional and interpersonal climate,

- Recognizing the impact of organizational decisions on people first,

- Acknowledging that serving in a leadership capacity includes a substantive emotional component,

- Anticipating the factors and events that may adversely impact the organization and its people in the future-and taking incremental steps to minimize that impact, and

- Making the hard decisions, such as choosing among the options that are in the best interests of people regardless of the financial outcomes or political implications.

In conclusion, Frost provides the reader with $a$ three-phase scheme for the systematic organizational management of toxicity, one that includes prevention, intervention, and restoration/recovery strategies.

Throughout Toxic Emotions at Work, Frost cites relevant references drawn from diverse management perspectives and provides pertinent anecdotes and scenarios that contribute to the work's richness. The author's style and approach make it a valuable source for students in graduate organizational behavior and human resource management courses as well as organizational leaders who are interested in creating a more humane and productive workplace.

\section{Value Shift: Why Companies Must Merge Social and Financial Imperatives to Achieve Superior Performance}

Reviewed by Carol Sánchez, Grand Valley State University

In Value Shift, Lynn Sharp Paine argues that modern corporations are now expected to meet 


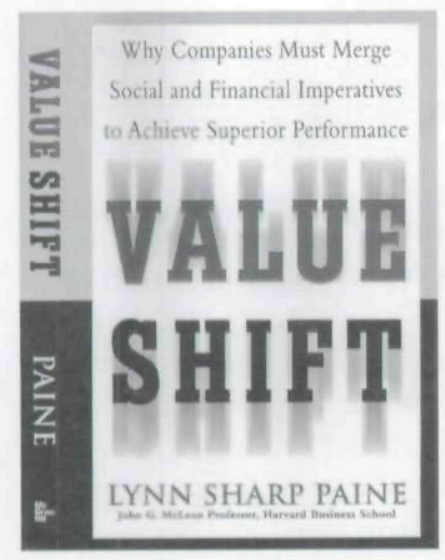

By Lynn Sharp Paine. New York, NY: McGraw-Hill, 2003. 302 pages, hard cover, $\$ 27.95$.

moral, as well as financial, performance standards to be considered superior performing firms. Paine calls this a return to, or a shift in, values that now emphasize ethics, culture, environmental standards, product safety, and community investment-what students of management might call a broad stakeholder model of the firm. The author, who is professor of leadership and values at the Harvard Business School, reflects on the recent crises in corporate America that began in 2001 with the Enron scandal. These disgraceful misdeeds and the public reaction to them support Paine's view that if corporations want to be considered as superior performing institutions, the public expects them to behave in morally as well as financially responsible ways.

If corporations want to be considered as superior performing institutions, the public expects them to behave in morally as well as financially responsible ways.

This book explores what executives say about this new value shift and why many of them are enthusiastic endorsers of superior moral and financial performance. Value Shift then explains what the value shift means to managers and executives, what is driving it, and why it is more important now than ever before. Finally, the book guides managers through the process of evaluating the social and financial imperatives of their own companies.

A major tenet of the book is the idea that the corporation has a personality or a true persona. The author outlines the history of the development of the modern corporation, beginning with its original legal establishment in English law as an amoral (not immoral) organization and reaffirmed by U.S. Chief Justice John Marshall in 1819 in Dartmouth College v. Woodward that the corporation is "an artificial being, invisible, intangible, and ex- isting only in contemplation of law." By the twentieth century, given the corporation's capacity to sue, be sued, enter into contracts, and enjoy constitutional protections, legal thinking shifted toward the idea that the corporation was a person, albeit an artificial person, with artificial responsibilities. In other words, as an artificial persona, the corporation enjoys unique rights but has little responsibility to its employees, customers, or the communities in which it operates. Paine argues that the idea of the corporation as an amoral, artificial person is outdated and is largely rejected by employees, customers, investors, and citizens who have been adversely affected by the illegal and, indeed, immoral behavior of many modern corporations. Thus, the expectation of corporations as true personae, with personalities, has emerged. Stakeholders know that corporate behavior has significant effects on society and hold corporations accountable for both the benefits and harms brought on by their actions.

Some individuals would object to holding companies accountable to a higher ethical standard. They claim that a company's principal fiduciary duty is to maximize financial gain for shareholders and that managers have no authority to recognize the claims of third parties by behaving in a proactively ethical way. In this sense, corporate ethical behavior sounds almost downright unethical if it means doing things that might compromise profits. Here is where Paine brilliantly argues in favor of value-driven corporate behavior by drawing on agency theory. If it is true that managers are hired to act as agents of shareholders, it is also true that shareholders are not insulated from responsibilities they would have if they managed the capital themselves. Put more simply, people have the duty to use their property in ways respecting the legitimate claims of others. They can not escape those duties by hiring someone else to manage their property for them. For example, the owner of an automobile is responsible for damage to third parties or property incurred by that automobile, whether the owner is driving it or not. In the same way, while corporate agents are obligated to create value for the shareholders, they are also obligated to avoid injury to third parties and, by extension, to behave in ways that respond to the needs of the broader stakeholder group to which they owe their existence.

Readers will probably be curious about what the author has to say about the link, if any, between social, ethical, and value-based corporate behavior and the firm's performance. Paine addresses this concern with a broad discussion on whether "ethics pays." First, she explains how illegal behavior and corporate crime have explicit costs such as fines, penalties, and damage payments, legal expenses to 
investigate, defend, and settle charges, and lost revenue as a result of customer defection. Second, she discusses actual and opportunity costs that a company often incurs when its inappropriate actions, though not illegal, and its inaction deceive stakeholders.

In 1991, executives of Salomon Brothers learned that some of its traders had submitted false bids to the U.S. Treasury's weekly securities auctions. Executives did not stop the behavior until several months later when it was discovered that they had known of it for some time. This "small" deception created by executive inertia ballooned out of control, and the company never fully recovered. In the short term, Salomon experienced revenue losses and higher costs as a result of its suspension from trading, lost productivity, employee defections, and a tarnished reputation reflected in stock and bond markets. It also lost several important clients, including CalPERS and the World Bank. Later it was sued by the U.S. Department of Justice and settled for \$290 million. Battered and shaken, the firm was acquired by the Travelers Group just a few years later.

Putting the costs of bad corporate behavior aside, do firms that proactively behave in valuedriven and ethically positive ways enjoy superior financial performance? Paine reviews several important studies suggesting that companies experiencing long-term financial success value leadership, fairness, and the interests of their stakeholders more than less financially successful companies do. More importantly, the author notes there is little evidence suggesting a negative relationship between social and financial performance. On the contrary, most studies suggest that companies with declared and practiced commitment to ethical and social principles tend to outperform their peers. Paine notes, "Although no study has convincingly measured corporate ethical competency and shown its positive relation to financial performance, one thing is quite clear. Ethics and financial self-interest are no longer the implacable enemies they have sometimes been thought to be ... the growing acceptance of 'ethics pays' is a remarkable shift from the 'ethics costs' stance of only a few decades back."

The book is an excellent review of modern thinking, by managers and academics, on the importance of combining corporate social and financial performance. It is a timely contribution in light of the scandalous behaviors over the past two years of some executives in charge of large U.S. and international firms. Practicing managers and those in academia interested in this topic will be particularly pleased with two very appealing characteristics of this book. First, the author gives us extensive case studies or reports of companieslarge, small, public, private, U.S., and international-that illustrate the shift in corporate values toward, although in a few cases away from, a merging of social and financial goals. Companies featured in excellent detail include AES Corporation, Bridgestone/Firestone, Columbia/HCA Healthcare, HDFC (India) Ltd., IBM (Argentina), Johnson \& Johnson, Manville Corporation, Quingdao (China) General Refrigerator Factory, Royal Dutch/Shell, Sealed Air Corporation, and Sunbeam.

\section{The book is an excellent review of modern thinking, by managers and academics, on the importance of combining corporate social and financial performance.}

The second fascinating component is a set of frameworks and questions designed to help managers consider how they might combine ethical and economic imperatives. The most important framework is what Paine calls the "compass for decisionmaking." She convinces us that an ethical analysis of a company's activities is rarely an integral part of managerial decision-making since ethical issues are generally managed by exception, instinct, and gut feel, rather than by informed thought.

To guide managerial instinct, Paine offers a method for integrating the moral point of view into managerial decision-making. The Compass for Decision Making incorporates four modes of moral analysis-purpose, principle, people, and powereach embracing practical reasoning and the basics of ethical thought. The four modes provide moral lenses that help managers identify the ethical issues that might be obscured by financially driven analysis. The Compass is likely to be a useful tool for those managers and decisionmakers interested in achieving superior moral, as well as financial, performance for their companies. Value Shift provides all the compelling arguments to help steer managers in that direction.

If you would like to suggest books for us to review or are interested in writing reviews, please contact Jeff Katz, Book Review Editor, at jkatz@ksu.edu. 
Copyright of Academy of Management Executive is the property of Academy of Management and its content may not be copied or emailed to multiple sites or posted to a listserv without the copyright holder's express written permission. However, users may print, download, or email articles for individual use. 